\title{
LABOUR MARKETS SITUATION IN EU COUNTRIES IN THE LAST TEN YEARS
}

\author{
[Situácia na pracovných trhoch krajín Európskej únie v poslednom desat'ročí]
}

\author{
Eva Rievajová ${ }^{1}$, Roman Klimko ${ }^{2}$ \\ ${ }^{1}$ Ekonomická univerzita v Bratislave, Národohospodárska fakulta, Dolnozemská 1, 85235 Bratislava \\ Email: eva.rievajova@euba.sk \\ ${ }^{2}$ Ekonomická univerzita v Bratislave, Národohospodárska fakulta, Dolnozemská 1, 85235 Bratislava \\ Email: roman.klimko@euba.sk
}

\begin{abstract}
The situation in the labour markets in EU countries after the onset of the financial and economic crisis has deteriorated significantly, while so called vulnerable groups have been affected more. Since the late 90s EU countries are oriented to promote employment growth, which is reflected in the documents and guidelines for individual Member States and approaches to find common solutions in the field of labour market and employment policy. For this purpose Europe 2020 strategy and follow-up documents and recommendations focused on growth performance, employment and competitiveness of the EU countries were adopted. The paper is focused on the characteristics of basic trends in the labour markets in the Member States, challenges and common procedures for employment growth and job creation.
\end{abstract}

Keywords: labour market, unemployment, labour market policy, European employment strategy.

JEL classification: J01, J08

Doručeno redakci: 5.9.2014; Recenzováno: 18.9.2014; 5.12.2014; Schváleno k publikování: 11.2.2015

\section{Úvod}

Údaje o nezamestnanosti a miere zamestnanosti sú dôležitými indikátormi ekonomického vývoja krajiny, jej konkurencieschopnosti i životnej úrovne obyvatel’ov. Slúžia ako dôležité informácie pre aplikáciu nástrojov hospodárskej politiky. Krajiny EÚ sa pri riešení nerovnováhy na trhu práce orientujú od konca 90-tych rokov na podporu rastu zamestnanosti, čo je premietnuté i v dokumentoch a usmerneniach pre jednotlivé členské štáty a v prístupoch $\mathrm{k}$ hl’adaniu spoločných riešení $\mathrm{v}$ oblasti trhu práce a politiky zamestnanosti. Finančná a hospodárska kríza zasiahla celú EÚ, hlboká recesia vo väčšine krajín EÚ spôsobila od roku 2008 výrazné zhoršenie výkonnosti trhov práce. Zo všeobecných makroekonomických zákonitostí je známe, že nezamestnanost' fluktuuje v závislosti od fázy ekonomického cyklu, $\mathrm{v}$ čase recesie či depresie rastie, $\mathrm{v}$ čase konjunktúry klesá. Rozdiely medzi členskými štátmi sa v mnohých ukazovatel’och týkajúcich sa zamestnanosti a sociálnej situácie prehíbili, vplyv na určité skupiny bol výraznejší, pričom najviac ovplyvnené boli už ohrozené osoby. Uvedenej problematike sa venuje široké spektrum literatúry, dostupná je konkrétna údajová báza (European Commission, 2012b) a detailne problematiku rozoberá napr. Šikulová a kol. (2014). Ciel'om článku je na jednej strane identifikovat' a zhodnotit' situáciu a trendy vývoja na európskych trhoch práce, čo je obsahom prvej kapitoly. Na druhej strane je cielom identifikovat' koordinačné tendencie pre oblast' zamestnanosti v rámci EÚ. Preto je druhá kapitola zameraná na Európsku stratégiu zamestnanosti, ktorá predstavuje v podmienkach EÚ hlavný nástroj na koordináciu úsilia členských štátov $\mathrm{v}$ oblasti trhov práce. V závere druhej kapitoly sú identifikované klúčové výzvy, ktorých ciel’om je mobilizácia zamestnanosti na účely rastu. 


\section{Trendy vývoja a situácia na európskych trhoch práce}

Najnovšie trendy na trhoch práce sú čiastočne výsledkom cyklických pohybov a najmä hlbokej hospodárskej krízy, ale sú spôsobené aj štrukturálnymi a inštitucionálnymi problémami trhu práce ovplyvňujúcimi ekonomickú činnost' a výkonnost' trhov práce. Kríza postihla EÚ nielen stratou výkonnosti, ale aj rastom nezamestnanosti a poklesom schopnosti vytvárat' nové pracovné miesta. S výnimkou roku 2010 čistá tvorba pracovných miest (rast zamestnanosti) stále klesala na úrovni EÚ aj v členských štátoch. Od polovice roka 2011 sa celá Európa vrátila spät' k záporným hodnotám miery rastu zamestnanosti. Je to celkový výsledok klesajúceho trendu $\mathrm{v}$ oblasti nachádzania pracovných miest (zamestnávania sa nezamestnaných) a rastúcich trendov separácie pracovných miest, ktorý si vyžaduje politiky na stimuláciu dopytu po pracovných silách a modelu rastu podporujúceho tvorbu pracovných miest. Aj v procese oživenia ekonomík je obnova a tvorba pracovných miest pomalšia ako v predkrízovom období aj ako dôsledok poklesu resp. stagnácie domácej spotreby a nastupuje časové oneskorenie medzi rastom ekonomiky a rastom zamestnanosti.

Konzekvencie globálnej ekonomickej krízy by sa dali podl'a Tomšíka (2010) zhrnút' nasledovne:

- $\quad$ prudké zhoršenie očakávania firiem a domácností,

- $\quad$ nárast problémov s financovaním obchodu, výroby, investícií,

- $\quad$ rast prepúšt'ania a miery nezamestnanosti,

- $\quad$ pokles súkromnej spotreby a investící́.

Napriek kríze sa miery aktivity $\mathrm{v}$ mnohých členských štátoch d’alej zvyšujú, a to predovšetkým v dôsledku zvyšovania miery aktivity u starších pracovníkov a žien (vo veku nad 55 rokov). Medzi 2. štvrt'rokom 2008 a 2. štvrt'rokom 2013 miera aktivity u osôb vo veku 15 - 64 rokov v EÚ-28 vzrástla zo 70,7 \% na 71,9 \%, aj ked' sa vyskytli značné rozdiely medzi jednotlivými krajinami. Miera aktivity sa zvýšila najvýraznejšie v ČR, Malte, Mad'arsku, zatial' čo najväčší pokles bola zaznamenaný v Dánsku (ale z vel'mi vysokej úrovne), Írsku a Chorvátsku.

Obrázok 1: Vývoj mier zamestnanosti v EÚ-28 vzhl'adom na ciele stratégie Európa 2020 (veková skupina $20-64$ rokov)

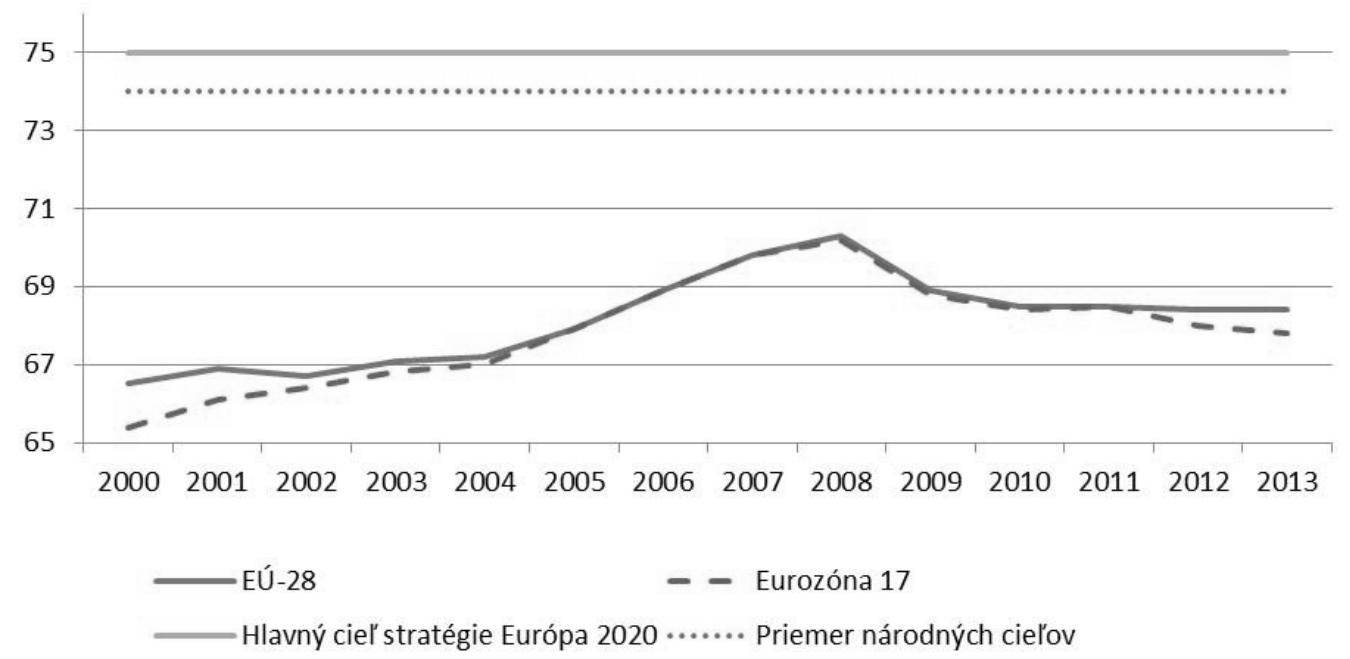

Zdroj: Eurostat.

Miera zamestnanosti v EÚ (European Commission, 2013b) v niekol'kých posledných rokoch stagnuje a zostáva nižšia než ciel'ových 75 \%, ktoré sa v stratégii Európa 2020 stanovili 
v súvislosti so zamestnanost'ou obyvatel'stva vo veku 20 - 64 rokov. Po plynulom rastúcom trende v rokoch 2000 až 2008, ked' miera zamestnanosti v EÚ vzrástla zo 66,6 \% na 70,3\%, klesla miera zamestnanosti v EÚ v roku 2009 na 68,9 \% v dôsledku hlbokého poklesu hospodárstva. V roku 2010 miera zamestnanosti d'alej klesla na 68,5\% a v podstate sa na tejto úrovni ustálila. V roku 2012 dosiahla úroveň $68,4 \%$ a od dosiahnutia ciel'ových $75 \%$ ju delí 6,6 percentuálneho bodu. Táto situácia je spôsobená kombináciou nepriaznivého vplyvu krízy a času potrebného na to, aby sa na trhoch práce odzrkadlili zlepšenia, ako aj pomalým tempom reforiem trhu práce $\mathrm{v}$ niektorých členských štátoch (European Commission, 2014). Ak vezmeme do úvahy, že sa v období roku 2012 očakávali len jej minimálne prírastky na roky 2013 a 2014, medzi rokmi 2015 a 2020 bude potrebný jej celkový rast o 6 p. b., čo je skutočne len v rovine teórie a len priblíženie sa k úrovni $75 \%$ bude vyžadovat' mimoriadne úsilie.

Obrázok 2 : Miera zamestnanosti EÚ 27 v rokoch 2000, 2012 a 2020

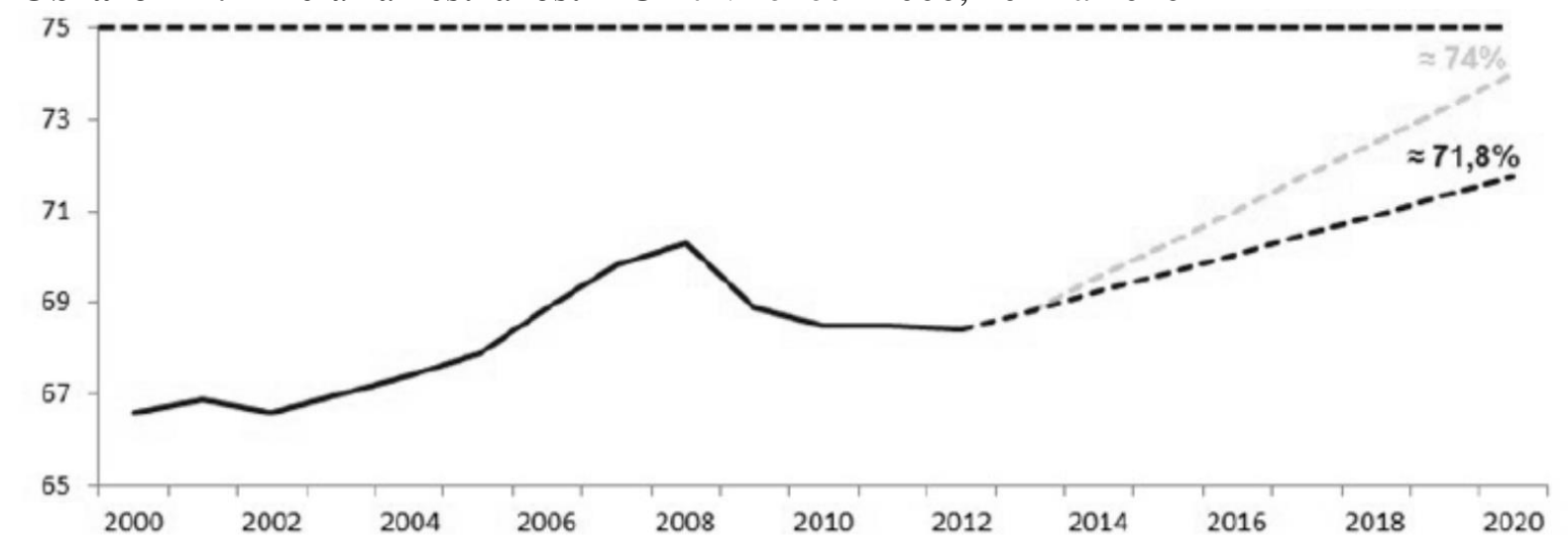

Zdroj: Európska komisia.

Legenda

... Vývoj za nezmenených okolností $(71,8 \%)$

... Ak budú splnené vnútroštátne ciele $(74 \%)$

Na základe súčasných záväzkov by miera zamestnanosti v EÚ mohla v roku 2020 dosiahnut úroveň 71,8 \%. 2000 a 2001.

Súčasná intenzita ekonomického rastu nepostačuje na tvorbu nových pracovných miest, rast zamestnanosti si vyžaduje vyšší ekonomický rast ako pred krízou. Podl'a prognóz Európskej komisie miera zamestnanosti sa $\mathrm{v}$ budúcich rokoch pravdepodobne mierne zvýši, a to najmä $\mathrm{v}$ dôsledku predpokladaného zvýšenia HDP. V súčasnom období miera vol’ných pracovných miest dosahuje približne $1,5 \%$, čo od konca roka 2010 predstavuje viac-menej priemer (Národná banka Slovenska, 2013). Z hl'adiska nastavajúcich rokov sa dá očakávat', že v strednodobom horizonte niekol'ko trendov povedie $\mathrm{k}$ d'alšiemu rastu počtu pracovných miest, najmä $\mathrm{v}$ niektorých oblastiach. Napríklad technický pokrok prispeje $\mathrm{k}$ vytvoreniu pracovných miest v sektore IKT (do roku 2015 sa očakáva 900000 neobsadených vol'ných odborných pracovných miest $\mathrm{v}$ oblasti IKT), zatial' čo starnutie obyvatel'stva napriek súčasným obmedzeniam vo verejných rozpočtoch na zdravotnú starostlivost' pravdepodobne zvýši v strednodobom horizonte dopyt po zdravotníckych pracovníkoch a zdravotníckych službách (a už v roku 2012 celkový počet osôb zamestnaných na poli zdravotníckych profesií v EÚ 27 dosiahol takmer milión). Okrem toho ekologizácia hospodárstva môže viest' $\mathrm{k}$ nárastu $\mathrm{v}$ oblasti ekologických pracovných miest. Aj d’alšie sektory súvisiace $\mathrm{s}$ oblast'ou špičkových technológií, ako napr. dopravný priemysel, si budú vyžadovat' nové pracovné sily so strednou až vysokou kvalifikáciou, aby sa prispôsobili rastu zaznamenanému v oblasti 
letectva a prepravy cestujúcich, pričom sa očakáva, že sektor dopravy do roku 2020 opustí vysoké percento starších pracovníkov (European Commission, 2013a).

Segmentácia na trhu práce je aj nad’alej výrazná. Podiel dočasných zamestnancov sa od roku 2011 zvýšil o 0,4 percentuálneho bodu, čo vo vel'kej miere odráža neistú ekonomickú situáciu. To prispieva $\mathrm{k}$ existujúcej vysokej nezamestnanosti a/alebo nízkej miere účasti určitých skupín. Zamestnanost' mládeže sa vyznačuje vysokým podielom dočasných pracovníkov, ktorých počet $\mathrm{v}$ roku 2012 predstavoval niečo cez $40 \%$ z celkovej zamestnanosti, a pracovníkov zamestnaných na kratší pracovný čas (30 \% z celkovej zamestnanosti v roku 2012). V práci na kratší pracovný čas sú nadmerne zastúpené ženy. $\mathrm{V}$ roku 2012 sa miera práce na kratší pracovný čas u žien nachádzala na úrovni 31,9\% v porovnaní s 8,4 \% u mužov. V Holandsku, Vel'kej Británii, Nemecku, Rakúsku a Belgicku pritom pracovalo viac ako 40 \% žien na kratší pracovný čas, čím sa výrazne znížila miera zamestnanosti meraná $\mathrm{v}$ ekvivalentoch plného pracovného času. Súčasné dočasné zmluvy a zmluvy na kratší pracovný čas, hoci sú do istej miery nedobrovol'né, môžu prispiet' k vytváraniu pracovných miest a zo strednodobého až dlhodobého hl'adiska môžu byt' odrazovým mostíkom k trvalým pracovným zmluvám a/alebo pracovným zmluvám na plný pracovný čas (napr. $\mathrm{v}$ prípade mladých l'udí). Segmentácia sa dá vnímat' z pohl'adu pretrvávajúcich rodových rozdielov pri odmeňovaní a nízkej miery prechodu k zmluvným formám práce, ktoré zamestnancom zabezpečujú väčšiu ochranu (European Commission, 2012b).

Obrázok 3: Vývoj špecifických mier nezamestnanosti v EÚ-28 (v \%, 2003 - 2013)

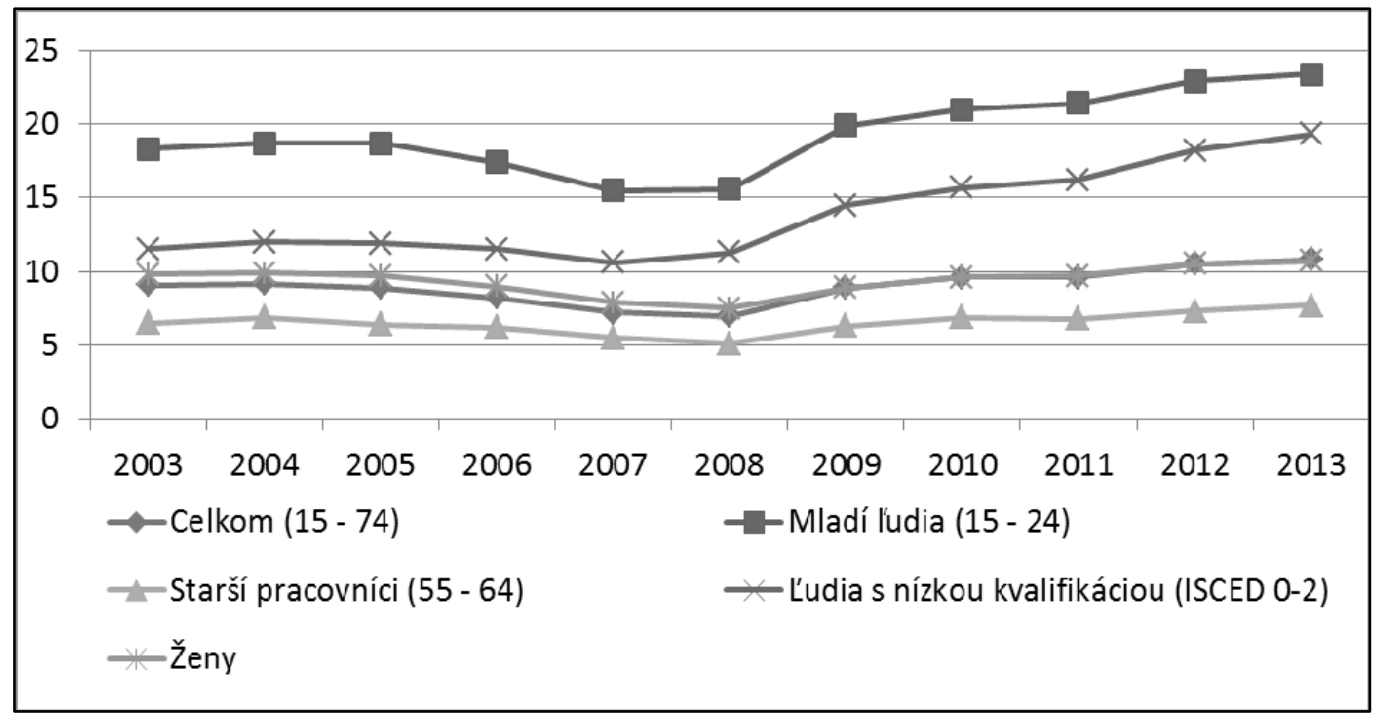

Poznámka: Údaje za rok 2013 sa vzt'ahujú na druhý štvrt'rok, údaje za obdobie rokov 2003 až 2012 sú ročné údaje.

Zdroj: Eurostat.

Miera nezamestnanosti prestala rást' v polovici roka 2013. Od začiatku roka 2013 zostala miera nezamestnanosti pomerne stabilná. V septembri 2013 celkový počet nezamestnaných dosiahol takmer 26,9 milióna l'udí (sezónne upravené). Zodpovedajúca miera predstavovala $11 \%$ a bola počas šiestich po sebe nasledujúcich mesiacov nezmenená. Trendy sa v rámci EÚ nepodobajú. V porovnaní so situáciou v septembri 2012 sa miera nezamestnanosti v 16 členských štátoch zvýšila (najviac v Španielsku, na Cypre, v Taliansku a Holandsku) a v 12 krajinách klesla (najsilnejšie v baltských štátoch, Írsku a Mad'arsku). Tieto rozdiely sú viacmenej v súlade s vývojom HDP vo všetkých členských štátoch. Nezamestnanost' vykazuje výrazné a narastajúce rozdiely medzi členskými štátmi, najmä v eurozóne. Od začiatku krízy sa miera nezamestnanosti výrazne zvýšila na juhu a periférii eurozóny, ale v iných členských 
štátoch bolo jej zvýšenie ovel'a menej výrazné. V auguste 2013 sa miera nezamestnanosti pohybovala od 4,9 \% v Rakúsku, 5,2 \% v Nemecku a 5,9 \% v Luxembursku do 26,6 \% v Španielsku a 27,6 \% v Grécku. Pokial' ide o zmeny v oblasti nezamestnanosti, najväčší medziročný nárast (medzi septembrom 2012 a septembrom 2013) sa zaznamenal na Cypre (+4,4 percentuálneho bodu). Vývoj bol pomerne negatívny aj v Holandsku (ale z nízkej úrovne) a v Taliansku.

Tabul'ka 1: Vývoj miery nezamestnanosti v EÚ-28 (v \%, 2010 - 2013)

\begin{tabular}{|c|c|c|c|c|}
\hline & 2010 & 2011 & 2012 & 2013 \\
\hline Belgicko & 8.3 & 7.2 & 7.6 & 8.4 \\
\hline Bulharsko & 10.3 & 11.3 & 12.3 & 12.9 \\
\hline Česká Republika & 7.3 & 6.7 & 7.0 & 7.0 \\
\hline Cyprus & 6.3 & 7.9 & 11.9 & 16.0 \\
\hline Dánsko & 7.5 & 7.6 & 7.5 & 7.0 \\
\hline Estónsko & 16.9 & 12.5 & 10.2 & 8,6 \\
\hline Európska únia & 9.7 & 9.7 & 10.5 & 10.9 \\
\hline Fínsko & 8.4 & 7.8 & 7.7 & 8.2 \\
\hline Francúzsko & 9.7 & 9.6 & 10.2 & 10.8 \\
\hline Grécko & 12.6 & 17.7 & 24.3 & 27.3 \\
\hline Holandsko & 4.5 & 4.4 & 5.3 & 6.7 \\
\hline Chorvátsko & 11.8 & 13.5 & 15.9 & 17.6 \\
\hline Írsko & 13.9 & 14.7 & 14.7 & 13.1 \\
\hline Litva & 17.8 & 15.4 & 13.4 & 11.8 \\
\hline Luxembursko & 4.6 & 4.8 & 5.1 & 5.9 \\
\hline Lotyšsko & 19.5 & 16.2 & 15.0 & 11.9 \\
\hline Mad'arsko & 11.2 & 10.9 & 10.9 & 10.2 \\
\hline Malta & 6.9 & 6.5 & 6.4 & 6.5 \\
\hline Nemecko & 7.1 & 5.9 & 5.5 & 5.3 \\
\hline Pol'sko & 9.7 & 9.7 & 10.1 & 10.3 \\
\hline Portugalsko & 12.0 & 12.9 & 15.9 & 16.5 \\
\hline Rakúsko & 4.4 & 4.2 & 4.3 & 4,9 \\
\hline Rumunsko & 7.3 & 7.4 & 7.0 & 7.3 \\
\hline Švédsko & 8.6 & 7.8 & 8.0 & 8.0 \\
\hline Slovinsko & 7.3 & 8.2 & 8.9 & 10.2 \\
\hline Slovensko & 14.5 & 13.7 & 14.0 & 14.2 \\
\hline Španielsko & 20.1 & 21.7 & 25.0 & 26.4 \\
\hline Taliansko & 8.4 & 8.4 & 10.7 & 12.2 \\
\hline Vel'ká Británia & 7.8 & 8.0 & 7.9 & 7,6 \\
\hline
\end{tabular}

Zdroj: Eurostat.

Podla informácií štatistického úradu Európskej únie Eurostat, bola miera nezamestnanosti v EÚ na začiatku r. 2014 na úrovni 12 \%. Nezamestnanost' na Slovensku bola šiesta najvyššia spomedzi krajín EÚ, má však mierne klesajúcu tendenciu. Najnižšiu nezamestnanost' malo Rakúsko, Nemecko a Luxembursko. Najvyššiu nezamestnanost' malo Grécko a Španielsko. Čo sa týka miery nezamestnanosti mladých (pod 25 rokov) v EÚ, drží sa na úrovni 24,0 \% (január 2014). Najnižšiu mieru nezamestnanosti mladých malo začiatkom roka 2014 Nemecko (7,6 \%), Rakúsko (10,5 \%) a Holandsko (11,1\%). Najvyššiu mieru nezamestnanosti mladých malo Grécko (59,0 \% november 2013), Španielsko (54,6 \%) a Chorvátsko $(49,8 \%$ koniec r. 2013) (Ministerstvo financií SR, 2013).

$\mathrm{Na}$ Slovensku nezamestnanost' rástla nižšśm tempom ako priemer za EÚ, Slovensko však patrilo medzi krajiny $\mathrm{s}$ najvyššou nezamestnanost’ou $\mathrm{v}$ EÚ. Jednotkové náklady práce 
na Slovensku nepatrne vzrástli. Vyššia dynamika produktivity práce sa premietla do zmeny relatívnej produktivity práce, ktorá sa vrátila na úroveň z roka 2010 (81% EÚ).

Dlhodobá nezamestnanost' je i nad’alej vážnym sociálno-ekonomickým problémom a rastie aj v dôsledku dlhého trvania krízy. Od roku 2008 sa počet dlhodobo nezamestnaných zhruba zdvojnásobil, pričom k nárastu došlo takmer vo všetkých členských štátoch okrem Nemecka (kde sa v období medzi rokmi 2008 a 2012 miera nezamestnanosti znížila zo 4 \% na 2,5\%) a Luxemburska (kde bola $\mathrm{v}$ tomto období miera nezamestnanosti stabilná na úrovni okolo 1,5 \%). V priebehu roka až do druhého štvrt'roka 2013 sa v EÚ-28 dlhodobá nezamestnanost' vyjadrená ako percento celkovej nezamestnanosti zvýšila zo $45 \%$ na 47,1 \% (v prípade Eurozóny zo 47,0 \% na 49,5\%).

Jedným z najzávažnejších problémov súčasnosti je vysoký podiel mladých osôb, ktoré majú problém nájst' si vhodné zamestnanie. Nezamestnanost' mladých je sledovaná podielom počtu nezamestnaných do veku 25 rokov voči ekonomicky aktívnemu obyvatel'stvu tejto vekovej skupiny. Percento mladých l’udí, ktorí nie sú zamestnaní, nepokračujú v procese vzdelávania ani odbornej prípravy (NEET), sa nad’alej zvyšuje. V období medzi rokmi 2008 a 2011 miera mladých l'udí v skupine NEET vo veku od 15 do 24 rokov vzrástla o 2 percentuálne body na 12,9 \% (obrázok 4). Miery NEET sú o niečo vyššie v prípade žien ako mužov: v roku 2012 predstavovali 13,4 \% u žien a 12,9 \% u mužov (spolu 13,1 \%). Jav NEET je spôsobený skôr nárastom nezamestnanosti mladých l'udí než nečinnost'ou súvisiacou s neúčast'ou na procese vzdelávania. V EÚ 28 je až 5,3 milióna mladých l'udí nezamestnaných, v decembri 2013 predstavovala nezamestnanost' mládeže viac ako $23,5 \%$, čo je nárast o 0,4 percentuálneho bodu v porovnaní s predchádzajúcim rokom. Medzi členskými štátmi existuje široký rozptyl údajov, pričom údaje za december 2013 sa pohybujú v rozmedzí od 7,7 \% v Nemecku a 8,7\% v Rakúsku do $56,5 \%$ v Španielsku a $57,3 \%$ v Grécku. V posledných mesiacoch sa tento rozdiel už prestal prehlbovat', no stále zostáva vel'ký.

Obrázok 4: Celková miera skupiny NEET v EÚ-28 (v \%, vo veku 15 - 24 rokov)

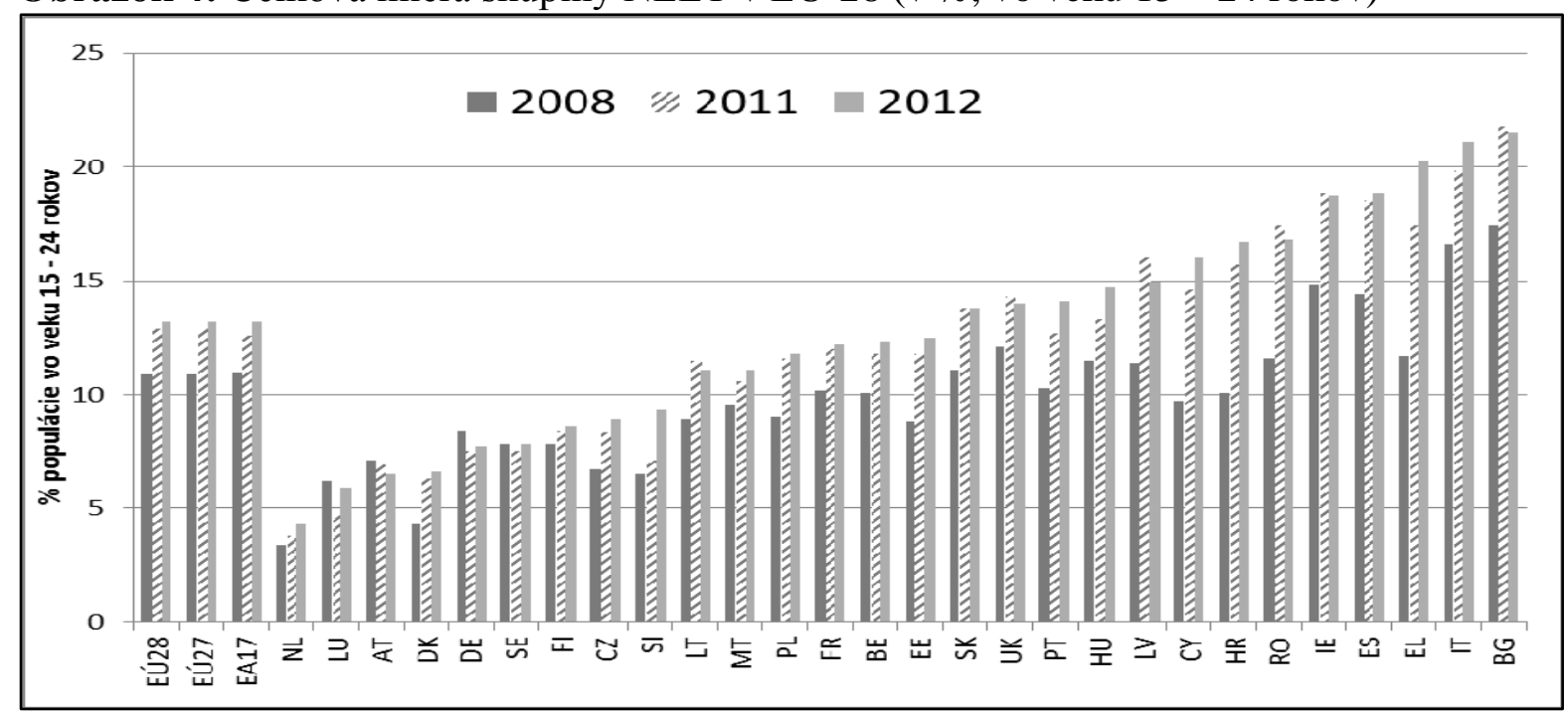

Zdroj: Eurostat.

Na problémy tak vysokej nezamestnanosti už reagujú aj štatistiky migrácie, kde hlavne v krajinách s najvyššou mierou nezamestnanosti mladých dochádza $\mathrm{k}$ vysokému negatívnemu migračnému saldu, ktoré je spôsobené hlavne vysokým počtom emigrantov z týchto krajín s ciel'om hl'adania si lepších sociálno-ekonomických možností za hranicami vlastnej krajiny. Ked’že EÚ podporuje jednotný trh, tak vyst’ahovanie a hl'adanie si práce v iných krajinách 
EÚ už v súčasnosti nie je vel'kým problémom a to využíva hlavne mladšia generácia obyvatel'ov krajín EÚ (Ministerstvo financií SR, 2013).

Boj proti nezamestnanosti mladých l'udí sa na summite EÚ v júni 2014 stal novou vel'kou výzvou. Nepriaznivú situáciu mladých bude EÚ riešit' aj tak, že na roky 2014 - 2016 vyčlenila $\mathrm{z}$ európskeho rozpočtu $6 \mathrm{mld}$. eur na projekt zamestnávania mladých s názvom Záruka pre mladých.

Pokles účinnosti zosúladenia ponuky práce $\mathrm{s}$ dopytom po práci a tým vyvolaná vysoká nezamestnanost' si vyžadujú potrebu zásahov zo strany verejných služieb zamestnanosti a aktívnych politík trhu práce. Potreba konsolidácie verejných financií v mnohých štátoch EÚ však nedovol'uje zvyšovat' objem finančných prostriedkov vynakladaných na aktívne opatrenia na trhoch práce. Preto sa vo väčšej miere zameriavajú na zvýšenie efektivity existujúcich nástrojov. Dostupné dáta $z$ Eurostatu vypovedajú o tom, že výdavky na aktívnu politiku trhu práce $\mathrm{v}$ predchádzajúcich rokoch kopírovali úroveň nezamestnanosti.

\section{Koordinovaný prístup členských štátov pri riešení zamestnanosti}

Jedným z najväčších problémov EÚ, ktorý má dopad na celý rad mikroekonomických i makroekonomických ukazovatel'ov, je nižšia konkurencieschopnost' ekonomiky EÚ v porovnaní s USA a Japonskom. Preto bola v roku 2000 prijatá tzv. Lisabonská stratégia, komplexná stratégia stanovujúca ciele EÚ do 10-tich rokov v oblasti ekonomickej, sociálnej a environmentálnej. Ciel'ovú úlohu v miere zamestnanosti do roku 2010 sa podarilo splnit' iba Holandsku. EÚ sa rozhodla pokračovat' v hlavnom cieli zvyšovania konkurencieschopnosti prostredníctvom novej stratégia Európa 2020, kde dochádza k stanoveniu komplexnejšieho ciel'a bez vzt'ahu k jednotlivým krajinám EÚ.

Európska stratégia zamestnanosti (ESZ) je $\mathrm{v}$ podmienkach EÚ hlavným nástrojom na koordináciu reformného úsilia členských štátov $\mathrm{v}$ oblasti trhu práce. ESZ sa usiluje o vytváranie tak väčšieho počtu, ako aj lepších pracovných miest v celej EÚ. V tomto zmysle sa inšpiruje rastovou stratégiou Európa 2020. ESZ poskytuje rámec pre členské štáty pre výmenu informácií, diskusie a koordináciu politík zamestnanosti. Je založená na ročnom prieskume rastu, ktorý stanovuje priority EÚ pre nasledujúci rok s ciel'om stimulovat' rast i tvorbu pracovných miest. Ročným prieskumom rastu začína európsky semester, ktorý podporuje užšiu koordináciu národných vlád $\mathrm{v}$ oblastiach ich hospodárskych a fiškálnych politík.

Inštitucionálnymi zložkami ESZ sú (European Commission, 2013c):

- $\quad$ usmernenia pre politiky zamestnanosti;

- $\quad$ národné programy reforiem;

- $\quad$ spoločná správa o zamestnanosti;

- $\quad$ špecifické odporúčania pre členské štáty.

Usmernenia pre politiky zamestnanosti každoročne navrhuje Európska komisia, následne sú odsúhlasené vládami členských štátov EÚ a prijíma ich Rada EÚ. Predstavujú spoločné priority a ciele pre politiky zamestnanosti. Usmernenia o zamestnanosti poskytujú stabilné politické usmernenia pre členské štáty, ako reagovat' na problémy súvisiace so zamestnanost'ou a sociálnou situáciou na pozadí súčasných trendov a s ciel'om dosiahnut' ciele stratégie Európa 2020. V ročnom prieskume rastu 2013 sa stanovujú priority a politické usmernenia pre členské štáty, ktoré v rámci európskeho semestra 2013 predkladali svoje národné programy reforiem. V súlade $\mathrm{s}$ tým sa národné programy reforiem preskúmali a Rada na základe návrhu Komisie vydala odporúčania pre jednotlivé krajiny. Výbory pre 
zamestnanost' a sociálnu ochranu preskúmali výsledky a dosiahnutý pokrok členských štátov v reakcii na príslušné problémy prostredníctvom uplatňovania Monitora výsledkov v oblasti zamestnanosti a Monitora výsledkov v oblasti sociálnej ochrany. Následné politické reformy sa budú posudzovat' v kontexte európskeho semestra 2014.

Vláda každého členského štátu zostavuje Národný program reforiem (NPR), ktorý predkladá Komisii a popisuje v ňom, ako sa jednotlivé usmernenia budú zavádzat' do praxe. Komisia následne správu posúdi, pričom dbá na to, aby stanovené národné ciele boli v súlade s ciel'mi na úrovni EÚ (v súčasnosti s ciel'mi stratégie Európa 2020).

Spoločná správa o zamestnanosti je založená na: (a) hodnotení situácie $\mathrm{v}$ oblasti zamestnanosti v EÚ; (b) implementácii usmernení pre politiky zamestnanosti a (c) posúdení návrhov národných programov reforiem Výborom pre zamestnanost'. Taktiež je súčast'ou ročného prieskumu rastu. Komisia prezentuje nový návrh a ciel'om je revízia usmernení pre politiky zamestnanosti na nasledujúci rok. Následne spoločnú správu o zamestnanosti prijíma Rada EÚ. Na základe hodnotenia národných programov reforiem a návrhu Komisie môže Rada EÚ kvalifikovanou väčšinou prijat' odporúčania pre jednotlivé členské štáty (European Commission, 2013b).

Členské štáty si stanovili nové priority, ktoré sú vyjadrené v piatich hlavných ciel'och EÚ, desiatich integrovaných usmerneniach a siedmich hlavných iniciatívach. $Z$ piatich hlavných ciel'ov môžeme vyčlenit' tri, ktoré majú priamu súvislost' $s$ trhom práce, zručnost'ami a sociálnymi politikami a sú podporované štyrmi integrovanými usmerneniami (European Commission, 2012a).

Tabul'ka 2: Hlavné ciele a integrované usmernenia pre zamestnanost' stratégie Európa 2020

\begin{tabular}{|c|c|}
\hline Hlavný ciel' EÚ & Integrované usmernenia \\
\hline Miera zamestnanosti 20 - 64 ročných $75 \%$. & $\begin{array}{l}\text { Zvyšovanie účasti na trhu práce a znižovanie } \\
\text { štrukturálnej nezamestnanosti. }\end{array}$ \\
\hline $\begin{array}{l}\text { Miera predčasného ukončenia školskej } \\
\text { dochádzky pod } 10 \% \text { a minimálne } 40 \% 30 \\
-34 \text { ročných s ukončeným VŠ vzdelaním. }\end{array}$ & $\begin{array}{l}\text { Rozvoj kvalifikovanej pracovnej sily } \\
\text { zodpovedajúcej potrebám trhu práce, } \\
\text { podpora kvality pracovných miest } \\
\text { a celoživotného vzdelávania. } \\
\text { Zlepšovanie výkonnosti systémov } \\
\text { vzdelávania a odbornej prípravy na všetkých } \\
\text { úrovniach a zvyšovanie účasti na } \\
\text { vysokoškolskom vzdelávaní. }\end{array}$ \\
\hline $\begin{array}{l}\text { Zníženie počtu osôb, ktorým hrozí chudoba } \\
\text { a sociálne vylúčenie aspoň o } 20 \text { miliónov. }\end{array}$ & $\begin{array}{l}\text { Podpora sociálneho začlenenia a boj proti } \\
\text { chudobe. }\end{array}$ \\
\hline
\end{tabular}

Zdroj: Vlastné spracovanie.

Stratégia Európa 2020 stanovila ciel' pre mieru zamestnanosti v roku 2020 na úrovni $75 \%$ pre vekovú skupinu 20 - 64 rokov. Tento ciel' bol schválený spolu so stratégiou v júni 2010. Napriek spoločnému záväzku na úrovni $75 \%$ za celú EÚ 27 v priemere, členské štáty oznámili vlastné ciele $\mathrm{v}$ miere zamestnanosti do roku 2020, a to vo svojich Národných programoch reforiem v roku 2011. Tie sa však podstatne líšia naprieč EÚ, kým Malta si stanovila ciel'ovú úroveň miery zamestnanosti vekovej skupiny 20 - 64 rokov na úrovni 62,9 \%, Dánsko a Holandsko $80 \%$ a Švédsko dokonca viac ako $80 \%$. Niektoré štáty ako Cyprus, Írsko, Rakúsko a Taliansko si stanovili ciel'ové rozpätie namiesto presnej úrovne a Vel'ká Británia nemá stanovený národný ciel'. Vol'ba jednotlivých vnútroštátnych ciel'ov má 
významné dôsledky pre dosiahnutie celkového ciel'a za EÚ. Zaujímavost'ou je skutočnost', že ak by členské štáty dosiahli svoje stanovené ciele pre rok 2020 a dosiahli by nižšiu hodnotu z ciel'ového pásma, priemerná miera zamestnanosti by bola 73,7 \% (ak vyššiu hodnotu z ciel'ového pásma, 74,0 \%). Čiže aj pri splnení jednotlivých národných ciel'ov by do výslednej, ciel'ovej miery zamestnanosti stále chýbalo $1,0-1,3$ p. b. (European Commission, 2012b).

V snahe reagovat' na pretrvávajúcu vysokú mieru nezamestnanosti a nízku mieru zamestnanosti v EÚ, Komisia v apríli 2012 predstavila súbor opatrení s jasným ciel’om, a síce podporit' vytváranie nových pracovných miest pod názvom „balík pre zamestnanost““. Balík pre zamestnanost' je súbor dokumentov, ktorý načrtáva možnosti, ako prepojit' politiky zamestnanosti na úrovni EÚ s radom d'alších politík na podporu inteligentného, udržatel'ného a inkluzívneho rastu (European Commission, 2012b).

Odporúčaním Rady Európskej únie z 22. apríla 2013 o zavedení záruky pre mladých l’udí bolo členským štátom EÚ odporučené zabezpečit', aby všetci mladí l'udia vo veku do 25 rokov dostali kvalitnú ponuku zamestnania, d’alšieho vzdelávania, učňovskej prípravy alebo stáže v lehote štyroch mesiacov po tom, čo prídu o zamestnanie alebo ukončia formálne vzdelanie. Ponuka d'alšieho vzdelávania by mohla zahŕňat' kvalitné programy odbornej prípravy, ktoré by viedli k uznávanej odbornej kvalifikácii (European Commission, 2013d).

Tabul'ka 3: Plnenie ciel'ov stratégie Európa 2020

\begin{tabular}{|c|c|c|c|c|c|c|}
\hline \multirow[b]{2}{*}{ Ukazovatel' } & \multicolumn{3}{|c|}{ Slovensko } & \multicolumn{3}{|c|}{ EÚ } \\
\hline & $\begin{array}{l}\text { Pôvodná } \\
\text { hodnota }\end{array}$ & \begin{tabular}{|c|} 
Aktuálna \\
hodnota
\end{tabular} & Ciel' & $\begin{array}{l}\text { Pôvodná } \\
\text { hodnota }\end{array}$ & \begin{tabular}{|} 
Aktuálna \\
hodnota
\end{tabular} & \begin{tabular}{|c} 
Ciel' \\
EÚ
\end{tabular} \\
\hline $\begin{array}{l}\text { Miera zamestnanosti (\% vo vekovej } \\
\text { skupine } 20-64 \text { rokov) }\end{array}$ & 66,4 & $65,1(+)$ & 72 & 69,0 & $68,5(-)$ & 75 \\
\hline Výdavky na vedu a výskum (\% HDP) & 0,47 & $0,68(+)$ & 1,0 & 1,96 & $2,03(+)$ & 3,0 \\
\hline $\begin{array}{c}\text { Miera vysokoškolsky vzdelanej populácie } \\
\text { (\% v skupine } 30 \text { - } 34 \text { rokov) }\end{array}$ & 15,8 & $23,7(+)$ & 40 & 31,5 & $35,8(+)$ & 40 \\
\hline $\begin{array}{c}\text { Predčasné ukončenie školskej dochádzky } \\
\text { (\% v skupine } 18-24 \text { rokov) }\end{array}$ & 6,0 & $5,3(-)$ & 6 & 16,6 & $12,8(+)$ & 10 \\
\hline $\begin{array}{l}\text { Populácia ohrozená chudobou a sociálnym } \\
\text { vylúčením (\% populácie) }\end{array}$ & 20,6 & $20,6(=)$ & 17,2 & 21,4 & $24,2(-)$ & 19,4 \\
\hline $\begin{array}{l}\text { Emisie skleníkových plynov mimo ETS } \\
\text { (zmena oproti roku } 2005 \mathrm{v} \% \text { ) }\end{array}$ & $-8,2$ & $-9,9$ & 13 & - & - & - \\
\hline $\begin{array}{c}\text { Podiel obnovitel'ných zdrojov energie na } \\
\text { hrubej konečnej spotrebe (\%) }\end{array}$ & 7,4 & $9,7(+)$ & 14 & 10,3 & $13,0(+)$ & 20 \\
\hline $\begin{array}{c}\text { Konečná energetická spotreba (zmena } \\
\text { oproti priemeru za } 2001-2005)\end{array}$ & $-3,1$ & $-2,5$ & -11 & - & $-1,8$ & - \\
\hline
\end{tabular}

V súčasnosti zostávajú aktuálne kl'účové výzvy, ktorých ciel’om je mobilizovat' zamestnanost' na účely rastu a prostredníctvom vyrovnaného prístupu založeného na flexiistote (Národná banka Slovenska, 2013):

- zníženie dlhodobej nezamestnanosti a boj proti neprijatel'ne vysokej nezamestnanosti mladých prostredníctvom včasnej aktivácie, 
- V kontexte čoraz väčšieho zhoršovania sa zosúladenia práce a zručností posilnit' služby zamestnanosti a aktívne politiky trhu práce,

- riešenie nesúladu medzi zručnost’ami v čase vysokej nezamestnanosti a t’aživá situácia mladých l'udí a žien, ktorí prichádzajú na trh práce alebo sa usilujú o trvalé uplatnenie, ilustrujú kl'účovú úlohu vzdelávania a odbornej prípravy a celkovú úroveň zručností pracovnej sily,

- d’alšie úsilie o zmodernizovanie právnych predpisov v oblasti zamestnanosti,

- zosúladenie vývoja v oblasti miezd a produktivity,

- znižovania daňového zat'aženia osobitných skupín,

- propagácia dlhšieho pracovného života, napríklad zvýšením veku skutočného odchodu do dôchodku a vykonávania stratégií aktívneho starnutia,

- podpora prostredia, ktoré je priaznivé pre podnikanie a zamestnanost',

- zabezpečenie toho, aby boli dávky $\mathrm{v}$ nezamestnanosti podmienené primeranými kritériami oprávnenosti,

- zabezpečovanie efektívnosti a účinnosti výdavkov na sociálnu ochranu,

- vykonávanie stratégie aktívneho začleňovania zamerané na najviac zranitel'né skupiny.

\section{Záver}

Vysoká nezamestnanost' vo väčšine krajín EÚ súvisí predovšetkým s poklesom, resp. nízkym ekonomickým rastom ako jedným z prejavov krízy po roku 2008. Najnovšie trendy na trhu práce sú čiastočne výsledkom cyklických pohybov a najmä hlbokej hospodárskej krízy, ale sú spôsobené aj štrukturálnymi a inštitucionálnymi problémami trhu práce ovplyvňujúcimi ekonomickú činnost' a výkonnost' trhov práce. Politika zamestnanosti pomáha vytvárat' podmienky s priaznivým vplyvom na tvorbu pracovných miest. $\mathrm{V}$ rámci balíka pre zamestnanost' je dôraz kladený predovšetkým na smerovanie dotácií na nábor pracovníkov. V súčasnosti sa $\mathrm{v}$ jednotlivých členských štátoch využívajú $\mathrm{v}$ značnej miere a zvyčajne sú orientované na znevýhodnené skupiny na trhu práce, ako sú napríklad mladí l'udia alebo dlhodobo nezamestnaní. V tejto súvislosti je však nutné dodat, že spomínané dotácie sú účinné len za predpokladu, že sú zamerané na nábor nových pracovníkov, inými slovami, pomocou nich by sa mali vytvárat' len také pracovné miesta, ktoré by inak nevznikli. Komisia rovnako odporúča znížit' daňovo-odvodové zat’aženie, bez vplyvu na rozpočet, čo sa má docielit' zvýšením environmentálnych, spotrebných daní a daní z nehnutel'ností. Pri tomto opatrení sa pozitívny vplyv očakáva $\mathrm{z}$ dlhodobého hl'adiska, najmä pri najzranitel'nejších skupinách na trhu práce, resp. pracovníkoch s nízkymi príjmami. Vysoká prepojenost' ekonomík vplýva na potrebu koordinácie štrukturálnych politík členských krajín EÚ, konsenzus o všeobecnom smerovaní hospodárskych politík a politík zamestnanosti členských krajín. Významnou iniciatívou EÚ je implementácia jednotného postupu pri podpore zamestnávania predovšetkým ohrozených skupín. Boj proti nezamestnanosti a sociálnym dôsledkom krízy preto musí byt' kl'účovou spoločnou prioritou Európy. Vyššia miera koordinácie hospodárskej politiky v celej EÚ, vyjadrená v rámci stratégie Európa 2020, by mala prispiet' k riešeniu problémov vyvolaných finančnou a ekonomickou krízou, k podpore ekonomického rastu, tvorbe pracovných miest a celkovému zvyšovaniu kvality života.

\section{Pod'akovanie}

Príspevok vznikol v rámci riešenia výskumného projektu VEGA č. 1/0103/12: „Trh práce vo väzbe na ekonomický rast v kontexte spoločensko-ekonomických zmien“" a projektu OP VaV S názvom „Vytvorenie excelentného pracoviska ekonomického výskumu pre riešenie civilizačných výziev v 21. storočí“ (ITMS 26240120032). Podporujeme výskumné aktivity na Slovensku. Projekt je spolufinancovaný zo zdrojov EÚ. 


\section{Literatúra}

[1] EUROPEAN COMMISSION, 2012a. Employment Package [online]. [vid. 18. júna 2014]. Dostupné z: http://ec.europa.eu/social/main.jsp?catId=1039\&langId=en

[2] EUROPEAN COMMISSION, 2012b. Key areas: comparing Member States' performances [online]. [vid. 21. júna 2014]. Dostupné z: http://ec.europa.eu/europe2020/ making-it-happen/key-areas/index_en.htm

[3] EUROPEAN COMMISSION, 2013a. European Economic Forecast - Spring 2013. Brussels: European Commission. ISBN 978-92-79-28534-9.

[4] EUROPEAN COMMISSION, 2013b. European employment strategy [online]. [vid. 17. júna 2014]. Dostupné z: http://ec.europa.eu/social/main.jsp?catId=101\&langId=en

[5] EUROPEAN COMMISSION, 2013c. Making it happen: the European Semester [online]. [vid. 22. júna 2014]. Dostupné z: http://ec.europa.eu/europe2020/making-ithappen/index_en.htm

[6] EUROPEAN COMMISSION, 2013d. Odporúčanie Rady z 22. apríla 2013 o zavedení záruky pre mladých l'udí [online]. [vid. 10. júna 2014]. Dostupné z: http://www.employment.gov.sk/files/slovensky/ministerstvo/medzinarodna-spolupraca/ europska-unia/strategie-europskej-unie/odporucanie-rady-z-22.-aprila-2013-o-zavedenizaruky-pre-mladych-ludi.pdf

[7] EUROPEAN COMMISSION, 2014. Prilohy $k$ oznámeniu komisie a Európskemu parlamentu, Rade, Európskemu hospodárskemu a sociálnemu výboru a Výboru regiónov. Zhodnotenie vykonávania stratégie Európa 2020 na zabezpečenie inteligentného, udržatel’ného a inkluzívneho rastu [online]. [vid. 23. júna 2014]. Dostupné $\quad \mathrm{z}: \quad \mathrm{http}: / /$ register.consilium.europa.eu/doc/srv?l=SK\&t=PDF\&f=ST+6713+ 2014+ADD+1

[8] MINISTERSTVO FINANCIÍ SLOVENSKEJ REPUBLIKY, 2013. Program stability Slovenskej republiky na roky 2013 až 2016 [online]. [vid. 16. júna 2014]. Dostupné z: http://ec.europa.eu/europe2020/pdf/nd/sp2013_slovakia_sk.pdf

[9] NÁRODNÁ BANKA SLOVENSKA, 2013. Analýza konvergencie slovenskej ekonomiky 2013 [online]. [vid. 18. júna 2014]. Dostupné z: http://www.nbs.sk/_img/Documents/PUBLIK/protected/ PP_01_2013_Lalinsky_Analyza _konvergencie_slovenskej_ekonomiky_2013.pdf

[10] RIEVAJOVÁ, E. a R. KLIMKO, 2014. New challenges of the European Employment Strategy for labour markets in the European Union. Nová ekonomika, 7(1), 24-36. Bratislava: Národohospodárska fakulta EU. ISSN 1336-1732.

[11] ŠIKULOVÁ a kol., 2014. Slovenská ekonomika: desat' rokov členstva v Európskej únii. Vybrané témy a problémy. Bratislava: VEDA, vydavatel'stvo Slovenskej akadémie vied. ISBN 978-80-7144-228-8.

[12] TOMŠÍK, V., 2010. Reakce měnové politiky ČNB na hospodářrkou krizi [online]. [vid. 20. júna 2014]. Dostupné $\mathrm{z}$ : http://www.cnb.cz/miranda2/export/sites/www.cnb.cz /cs/verejnost/pro_media/konference_projevy/vystoupeni_projevy/download/tomsik_2010 0612_dod.pdf 